\section{PERINATAL SOCIOECONOMIC AND GEOGRAPHICAL FACTORS AND RISK \\ OF CELIAC DISEASE IN CHILDREN: A MULTILEVEL ANALYSIS OF THE SWEDISH POPULATION}

\section{C.J. Wingren ${ }^{1}$, S. Björck ${ }^{2}$, K. Lynch ${ }^{1}$, H. Ohlsson ${ }^{1}$, D. Agardh², J. Merlo ${ }^{1}$ \\ ${ }^{1}$ Unit for Socialepidemiology, ${ }^{2}$ Unit for Diabetes and Celiac Disease, Lund University, Malmö, \\ Sweden}

In Sweden, a precipitous rise in the incidence of celiac disease (CD) in children below two years of age occurred during 1985-1995 in Sweden. The period is well suited for investigating the socioeconomic and geographical distribution of CD in Sweden. Previous research on the importance of socioeconomic position (SEP) in CD has produced conflicting results. All singleton children born in Sweden 1987-1993 were identified in the Swedish Medical Birth Record. We linked several other national registries to obtain socioeconomic, medical, and demographic information. We applied multilevel (counties, municipalities, and individuals) logistic regression methods to quantify a possible geographical clustering of CD cases and to investigate the association between SEP and CD. Using equalized family income quintile groups as a measure of SEP, we found that in the lowest quintile group the association with CD was for boys OR 1.18 (95\% Cl 0.90-1.55) and for girls OR 0.82 (95\% Cl $0.67-1.00)$. Using the Median Odds Ratio (MOR) as a measure of geographical variation clustering, we found that for boys the MOR was 1.76 (95\% Crl 1.46-2.00) and for girls 1.92 (95\% Crl 1.49-2.30). We also identified a reduced odds of CD in offspring having a mother born outside Sweden, boys OR 0.75 (95\% Cl 0.57-0.98) and girls OR 0.64 (95 $\% \mathrm{Cl} 0.51-0.79)$. The study show that SEP is of minor importance in the distribution of CD among small children. However, we identified a significant geographical clustering of CD in Sweden during 1987-1993.

\section{VARYING PREDICTIVE VALUES DICTATE THE NEED TO STANDARISE COMMERICAL KITS FOR TTG TESTING}

\section{Kesavelu}

Paediatric Gastroenterology, Alder Hey Childrens NHS Foundation Trust, Liverpool, UK

Background: Over the previous several months we have noticed an increased false positive coeliac serology rate in patients referred from a particular catchment area of our centre. We investigated serologic methods employed and compared it to methods used at our centre and other hospitals in our catchment.

Methods: We investigated serological methods employed to screen 69 patients referred for histological conformation of coeliac disease to our service in the previous year (2008). Pathology departments in referring hospitals were contacted to ascertain serological methods used. Coeliac disease was diagnosed based on biopsy evidence (gold standard). Predictive values for the screening serological tests were calculated.

Results are summarised in the following table.

tTG Values (see table)

\begin{tabular}{|l|l|l|l|l|l|}
\hline $\begin{array}{l}\text { HOS- } \\
\text { PITAL }\end{array}$ & $\begin{array}{l}\text { tTG Ag } \\
\text { prepa- } \\
\text { ration }\end{array}$ & $\begin{array}{l}\text { tTG } \\
\text { positive } \\
\text { cut off }\end{array}$ & $\begin{array}{l}\text { Positive } \\
\text { serology }\end{array}$ & $\begin{array}{l}\text { Positive } \\
\text { biopsy }\end{array}$ & $\begin{array}{l}\text { Positive } \\
\text { predictive } \\
\text { value }\end{array}$ \\
\hline A & $\begin{array}{l}\text { Phadia } \\
\text { Cellikey }\end{array}$ & $>7$ & 47 & 46 & 97.8 \\
\hline B & $\begin{array}{l}\text { Euro } \\
\text { immun }\end{array}$ & $>20$ & 15 & 3 & 16.66 \\
\hline C & $\begin{array}{l}\text { Phadia } \\
\text { ELISA }\end{array}$ & $>4$ & 4 & 2 & 50 \\
\hline D & $\begin{array}{l}\text { Fluro- } \\
\text { metric } \\
\text { testing }\end{array}$ & $>8$ & 1 & 1 & 100 \\
\hline E & Diasorin & $>8$ & 2 & 1 & 50 \\
\hline
\end{tabular}

[tTG Values]

Conclusions : Positive predictive values vary significantly between commercially available tTG kits. When faced with a high false positive trend it is worthwhile investigating laboratory methods used, bench marking against reference laboratories and standardising serological testing. 